Images in...

\title{
Diaphragmatic eventration misdiagnosed as dextrocardia
}

\author{
Amalia Boufidou, ${ }^{1}$ Adam Tsaousidis, ${ }^{1}$ Ioannis Chryssogonidis, ${ }^{2}$ Ioannis Stiliadis ${ }^{1}$ \\ ${ }^{1}$ 1st Cardiology Department, AHEPA University Hospital, Aristotle University of Thessaloniki, Thessaloniki, Greece; \\ ${ }^{2} 1$ st Radiology Department, AHEPA University Hospital, Aristotle University of Thessaloniki, Thessaloniki, Greece
}

Correspondence to Mr Adam Tsaousidis, adamtsaou@hotmail.com

\section{DESCRIPTION}

A 70-year-old woman, with reported dextrocardia, presented with retrosternal, stabbing pain with radiation to the precordial area and reflection on the left shoulder after meals. The pain aggravates in the supine position while it subsides in the sitting. The apex heart sounds were audible only in the left lateral position and disappeared at the supine position. The auscultation did not reveal any pathological sounds or murmurs. The chest x-ray revealed left diaphragmatic eventration figure $1 \mathrm{~A}$. The radiographic findings (aortic arch on the left) and the ECG, (positive ORS complex in lead I, negative in aVR, while limp leads placed in the ordinary position) called the mentioned history of dextrocardia into question. Furthermore, it aroused the suspicion of retrosternal pain as a result of diaphragm's compression to the heart due to the stomach entrance into the thoracic cavity. ${ }^{1} 2$ A thoracic CT scan figure $1 \mathrm{~B}$ excluded the dextrokardia and confirmed the left diaphragmatic eventration with entrance of the fornix of stomach and the left flexure of colon with displacement of the heart to the right side of the mediastinum (explaining the diminished heart sounds). The fornix of the stomach arised $2 \mathrm{~cm}$ underneath the tracheal bifurcation. The patient underwent a single photon emission CT heart scan without evidence of ischaemia and a gastroscopy which revealed an image of mesenteroaxial gastric volvulus without evidence of gastric ulcer. The known medical history did not confirm any cause of the diaphragmatic eventration. The patient was advised to eat small meals. Following our instructions she reported disappearance of her symptoms.

Competing interests None.

Patient consent Obtained.

\section{REFERENCES}

1. Gunatunga IP, Ansari J, Andrews R. Acute anterior myocardial infarction obscured by diaphragmatic eventration. Heart 2003;89:556.

2. Duerst UN, Husmann L, Kaufmann PA. Echocardiographic and 64-multislice computed tomographic manifestation of upside down stomach simulating a compression of the left atrium. Eur Heart J 2009;30:2896.
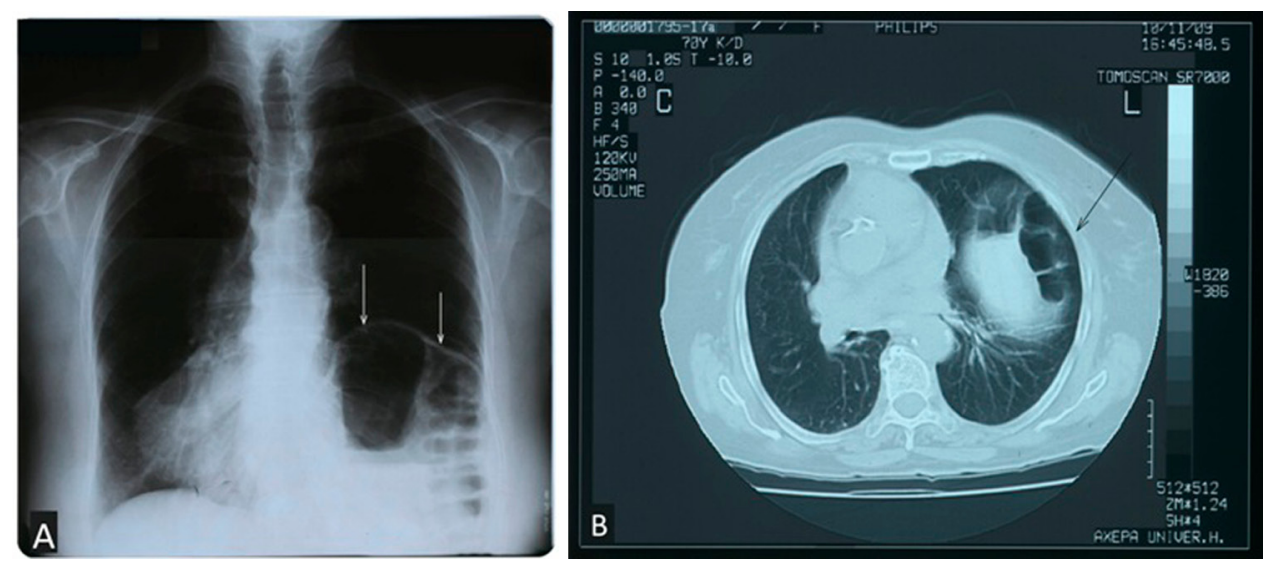

Figure 1 (A) Left diaphragmatic eventration with displacement of the heart to the right mediastinum. (B) Left diaphragmatic eventration with entrance of the fornix of stomach and the left flexure of colon with displacement of the heart to the right side of the mediastinum. 


\section{BMJ Case Reports}

This pdf has been created automatically from the final edited text and images.

Copyright 2011 BMJ Publishing Group. All rights reserved. For permission to reuse any of this content visit http://group.bmj.com/group/rights-licensing/permissions.

BMJ Case Report Fellows may re-use this article for personal use and teaching without any further permission.

Please cite this article as follows (you will need to access the article online to obtain the date of publication).

Boufidou A, Tsaousidis A, Chryssogonidis I, Stiliadis I. Diaphragmatic eventration misdiagnosed as dextrocardia. BMJ Case Reports 2011; 10.1136/bcr.07.2011.4429, date of publication

Become a Fellow of BMJ Case Reports today and you can:

- Submit as many cases as you like

- Enjoy fast sympathetic peer review and rapid publication of accepted articles

- Access all the published articles

Re-use any of the published material for personal use and teaching without further permission

For information on Institutional Fellowships contact consortiasales@bmjgroup.com

Visit casereports.bmj.com for more articles like this and to become a Fellow 